\title{
Effect of Management Practices Applied to Cover Crops with Bio- fumigation Properties on Cover Crop Performance and Weed Control in a Vineyard
}

\author{
J.C. Fourie ${ }^{1 *}$, D.H.M. Kruger ${ }^{2}$, A.P. Malan ${ }^{2}$
}

(1) ARC Infruitec-Nietvoorbij, Private Bag X5026, Stellenbosch, 7599 South Africa

(2) Department of Conservation Ecology and Entomology, Stellenbosch University, Private Bag X1, Matieland 7602, Stellenbosch, South Africa

Submitted for publication: September 2014

Accepted for publication: October 2014

Key words: Bio-fumigation crop, cover crop, grapevine, soil cultivation, weed control

\begin{abstract}
This five-year trial (2009 to 2013) was carried out in a full-bearing seven-year-old Shiraz/101-14 vineyard established on a sandy to sandy clay loam soil at Blaauwklippen farm $\left(33^{\circ} 58^{\prime} \mathrm{S}, \mathbf{1 8}^{\circ} 50^{\prime} \mathrm{E}\right)$ near Stellenbosch, South Africa. Fourteen treatments were applied, consisting of two management practices applied to five cover crop species, winter-growing weeds (no cover crop), and winter-growing weeds (no cover crop) combined with a nematicide application in the vine row. The dry matter production (DMP) increased between 0.55 and 2.62 t/ha from 2009 to 2010 for the small-seeded Sinapis alba cv. Braco (white mustard), Brassica napus cv. AVJade (canola), Brassica juncea cv. Caliente 199 (Caliente) and Eruca sativa cv. Nemat (Nemat). This was attributed to the finer seedbed that could be created. All cover crops suppressed the winter-growing weeds throughout the study. Although the stand of summer-growing weeds differed significantly between treatments in 2010, 2011 and 2012, the cover crop treatments did not suppress these weeds significantly. However, for the duration of the study, the weed stand in the canola controlled chemically full surface (CC) during grapevine bud break tended to be lower than that of the canola controlled mechanically (MC) during grapevine bud break. The same trend occurred between CC and MC for Avena sativa cv. Pallinup (Pallinup oats) and the treatments in which no cover crops were sown, with the exception of in 2009 and 2010 respectively.
\end{abstract}

\section{INTRODUCTION}

Soil-borne pests have a negative impact on food production in most agricultural crops. The phasing out of effective chemical control options causes the control of soil-borne pests, inter alia nematodes, to become an even greater challenge. Therefore, alternative methods of control, such as bio-fumigation (Matthiessen \& Kirkegaard, 2006), should be considered. Brassica species, which have the ability to suppress nematodes (Mojtahedi et al., 1991; McLeod \& Steel, 1999; Melakeberhan et al., 2006; Kruger et al., 2013), showed promising results as part of an integrated approach directed at nematode suppression in vineyards when they were mechanically incorporated into the soil (Rahman \& Somers, 2005). Cover crops that are currently used in the vineyards of South Africa have also been studied for their effect on nematodes (Addison \& Fourie, 2008). It was observed that two oats species, namely Avena sativa cv. Overberg and Avena strigosa cv. Saia, were poor hosts for Meloidogyne spp. (root-knot nematodes) and Mesocriconema xenoplax respectively.

Uncontrolled weeds may reduce crop yield by as much as $80 \%$ (Cousens \& Mortimer, 1995). This necessitates effective and sustainable weed control. The increasing number of weed species developing resistance to herbicides (LeBaron \& McFarland, 1990; LeBaron, 1991; Powles et al., 1997; Westra et al., 2008) make the use of cover crops as a non-specific biological method of pre-emergence weed control in vineyards essential (Van Huyssteen et al., 1984; Fourie, 2005; Fourie et al., 2005; 2006; Fourie \& Raath, 2008; Fourie, 2010; Fourie et al., 2011).

Compared to bare soils, cover crops controlled chemically or that die back naturally to form a mulch during the grapevine growing season reduce water runoff and erosion (Khan et al., 1986; Roth et al., 1988; Louw \& Bennie, 1992) and restrict evaporation from the soil surface (Van Huyssteen et al., 1984; Myburgh, 1998). They also conserve soil water (Buckerfield \& Webster, 1996; Myburgh, 2013) and reduce temperature fluctuations in the soil (Van Huyssteen et al., 1984; Fourie \& Freitag, 2010).

The aim of this study therefore was to determine the performance and weed-suppressing ability of cover crops selected for their bio-fumigation properties when controlled

*Corresponding author: E-mail address: fouriej@arc.agric.za

Acknowledgements: The authors would like to thank the Agricultural Research Council, Winetech, Dried Fruit Technical Services and the National Research Foundation of South Africa (NRF-THRIP TP2009072100026), for financial support, the staff of Soil and Water Science at ARC Infruitec-Nietvoorbij, for technical support, as well as Blaauwklippen Wine Estate, for supplying the trial site 
chemically or incorporated mechanically into the topsoil during grapevine bud break.

\section{MATERIALS AND METHODS \\ Experiment vineyard and layout}

The trial was conducted over five consecutive seasons (from $2009 / 2010$ to $2013 / 2014$ ) in a full-bearing, seven-year-old Shiraz/101-14 vineyard established on a sandy (0 to 300 $\mathrm{mm}$ soil layer) to sandy clay loam (300 to $600 \mathrm{~mm}$ soil layer) soil at Blaauwklippen farm (33⒌'S, $\left.18^{\circ} 50^{\prime} \mathrm{E}\right)$ near Stellenbosch in the Western Cape, South Africa (Table 1). Stellenbosch receives an average annual rainfall of $673 \mathrm{~mm}$, of which approximately $73 \%$ precipitates from March to August. The Shiraz vines were spaced $1.2 \mathrm{~m}$ in the row and $2.5 \mathrm{~m}$ between rows and trained onto a Perold trellis system (Booysen et al., 1992). Fourteen treatments (Table 2) were replicated three times in a fully randomised block design. The treatments consisted of five cover crop species managed according to two management practices (10 treatments). These were compared to two treatments in which no cover crop was sown and the weeds were managed according to the above-mentioned two management practices, as well as to two similar treatments in which a nematicide (Rugby 10ME) was applied to the vine row at $15 \mathrm{~mL} / \mathrm{m}^{2}$. Each replication plot covered an area of $81 \mathrm{~m}^{2}$. A work row and two vine rows functioned as a buffer zone between treatments in different work rows, and five vines acted as a buffer zone between the experiment vines of treatment plots that were situated in the same vine row.

Seedbed preparation in the work row was done with a disc harrow to a depth of approximately $150 \mathrm{~mm}$ (two passes in opposite directions). The seeds, after being broadcast by hand at the seeding densities indicated in Table 2, were covered by means of shallow cultivation (approximately $30 \mathrm{~mm}$ deep) with a rotary harrow. During the 2009/2010 to $2012 / 2013$ seasons, the cover crops were sown annually during early May (seeding dates varying between 4 and 10 May), after the first winter rain in excess of $16 \mathrm{~mm}$. The late onset of winter rain in 2013 resulted in the cover crops not being established until 23 May. At the beginning of the trial in April 2009, a fine seedbed could not be created as a result of excessive weed growth in the work row and a slight furrow in the centre of the work row, causing the vine rows to be slightly ridged. After sowing, the seeds were

TABLE 1

Characterisation of the 0 to $300 \mathrm{~mm}$ and 300 to $600 \mathrm{~mm}$ soil layers of the sandy to sandy loam soil in the Stellenbosch district, determined before the treatments commenced.

\begin{tabular}{|c|c|c|c|c|c|c|c|c|c|c|c|c|c|}
\hline \multirow[b]{2}{*}{ Soil layer } & \multirow{2}{*}{$\begin{array}{l}\text { Clay } \\
(\%)\end{array}$} & \multirow{2}{*}{$\begin{array}{l}\text { Silt } \\
(\%)\end{array}$} & \multirow{2}{*}{$\begin{array}{c}\text { Sand } \\
(\%)\end{array}$} & \multirow{2}{*}{$\begin{array}{c}\text { Stone } \\
(\text { Vol \%) }\end{array}$} & \multirow{2}{*}{$\begin{array}{c}\mathrm{pH} \\
(\mathrm{KCl})^{1}\end{array}$} & \multirow{2}{*}{$\begin{array}{l}\text { Electrical } \\
\text { conductivity }^{1} \\
(\mathrm{dS} / \mathrm{m})\end{array}$} & \multirow{2}{*}{$\begin{array}{l}\text { Organic } \\
\mathrm{C}^{1}(\%)\end{array}$} & \multirow{2}{*}{$\begin{array}{c}\mathrm{P} \\
(\text { Bray II })^{1} \\
(\mathrm{mg} / \mathrm{kg})\end{array}$} & \multirow{2}{*}{$\begin{array}{c}\mathrm{K} \\
\left(^{(B r a y ~ I I}\right)^{1} \\
(\mathrm{mg} / \mathrm{kg})\end{array}$} & \multicolumn{4}{|c|}{$\begin{array}{l}\text { Exchangeable cations }^{1} \\
(\mathrm{cmol}(+) / \mathrm{kg})\end{array}$} \\
\hline & & & & & & & & & & $\mathrm{Ca}$ & $\mathrm{Mg}$ & $\mathrm{K}$ & $\mathrm{Na}$ \\
\hline $0-300 \mathrm{~mm}$ & 7.0 & 4 & 89 & 35 & 6.1 & 0.06 & 0.66 & 25 & 30 & 3.67 & 0.30 & 0.08 & 0.07 \\
\hline $300-600 \mathrm{~mm}$ & 24.0 & 6 & 70 & 45 & 5.0 & 0.06 & 0.47 & 9 & 14 & 2.41 & 0.48 & 0.04 & 0.08 \\
\hline
\end{tabular}

${ }^{1}$ The average values of the 0 to $75 \mathrm{~mm}, 75$ to $150 \mathrm{~mm}$ and 150 to $300 \mathrm{~mm}$ layers are presented.

TABLE 2

Treatments applied in a Shiraz/101-14 vineyard established on a sandy to sandy clay loam soil near Stellenbosch.

\begin{tabular}{|c|c|c|c|}
\hline $\begin{array}{l}\text { Treatment } \\
\text { number }\end{array}$ & Cover crops & $\begin{array}{l}\text { Management } \\
\text { practice }\end{array}$ & $\begin{array}{l}\text { Seeding } \\
\text { density }(\mathrm{kg} / \mathrm{ha})\end{array}$ \\
\hline 1 & Avena sativa L. cv. Pallinup (Pallinup oats) & $\mathrm{CC}^{1}$ & 100 \\
\hline 2 & Pallinup oats & $\mathrm{MC}^{2}$ & 100 \\
\hline 3 & Sinapis alba cv. Braco (white mustard) & $\mathrm{CC}$ & 8 \\
\hline 4 & White mustard & $\mathrm{MC}$ & 8 \\
\hline 5 & Brassica napus cv. AVJade (canola) & $\mathrm{CC}$ & 8 \\
\hline 6 & Canola & $\mathrm{MC}$ & 8 \\
\hline 7 & Brassica juncea cv. Caliente 199 (Caliente) & $\mathrm{CC}$ & 10 \\
\hline 8 & Caliente & $\mathrm{MC}$ & 10 \\
\hline 9 & Eruca sativa cv. Nemat (Nemat) & $\mathrm{CC}$ & 5 \\
\hline 10 & Nemat & $\mathrm{MC}$ & 5 \\
\hline 11 & No cover crop (weeds) & $\mathrm{CC}$ & $\mathrm{NA}^{3}$ \\
\hline 12 & Weeds & $\mathrm{MC}$ & NA \\
\hline 13 & Weeds + nematicide (Rugby 10ME@15 mL/m²) & $\mathrm{CC}$ & NA \\
\hline 14 & Weeds + nematicide & $\mathrm{MC}$ & NA \\
\hline
\end{tabular}

${ }^{1}$ Full-surface chemical control from just before bud break to grapevine harvest. ${ }^{2}$ Chemical control in the vine row and mechanical cultivation in the work row just before bud break, $\mathrm{CC}$ from berry set. ${ }^{3} \mathrm{NA}$, Not applicable. 
covered by means of a light cultivation action to ensure good seed/soil contact. The slanted soil surface caused a large percentage of the seeds to accumulate in the middle of the work row. The mechanical cultivations applied during the first year levelled the soil in the work row to the extent that seedbed preparation and the covering of the broadcast seeds were achieved over the full surface from the second season (2010/2011) onwards.

The cover crops were controlled between late bloom and early seed/pod formation, which coincided with grapevine bud break. Two management practices were applied. Fullsurface, post-emergence weed control was achieved with glyphosate at a rate of $1.8 \mathrm{~kg} / \mathrm{ha}(\mathrm{CC})$, after which the cover crops/weeds were left standing to be flattened by tractor traffic during the grapevine growing season. In the treatments cultivated mechanically (MC), mechanical maceration of the cover crops was achieved by slashing the crops with a standard weed slasher and incorporating the fibre to a depth of $200 \mathrm{~mm}$ with a disc harrow immediately thereafter. In these treatments, chemical weed control was applied to the vine row with glyphosate at a rate of $0.6 \mathrm{~kg} / \mathrm{ha}$. The mechanical incorporation of the cover crop fibre was done before the soil started drying out, as water plays an important role (hydrolysis) during bio-fumigation (Matthiessen et al., 2004). This was not always possible, however, as rainfall was required to ensure sufficient soil moisture in the work row. If the soil moisture level is $66 \%$ of field water capacity at the time of incorporation, irrigation or rainfall is not essential, as bio-fumigation can still be expected to take place (L. Lazzeri, personal communication, 2012). Full-surface, postemergence weed control was achieved in both the MC and $\mathrm{CC}$ treatments during the first week of December by applying glyphosate at a rate of $1.8 \mathrm{~kg} / \mathrm{ha}$.

\section{Fertilisers applied}

To optimise biomass production, Brassica juncea cv. Caliente 199 (Caliente) and Eruca sativa cv. Nemat (Nemat) require approximately $120 \mathrm{~kg} /$ ha nitrogen $(\mathrm{N})$ and 60 to 80 $\mathrm{kg} / \mathrm{ha} \mathrm{N}$ respectively, depending on the fertility of the soil (D. Gies, personal communication, 2007). At the two- to six-leaf stages of a grain cover crop, $28 \mathrm{~kg} / \mathrm{ha} \mathrm{N}$ should be applied to optimise dry matter production (DMP) (Fourie \& Raath, 2008; Fourie et al., 2011). Brassica napus (canola) requires approximately 90 to $110 \mathrm{~kg} / \mathrm{ha} \mathrm{N}, 24 \mathrm{~kg} / \mathrm{ha}$ phosphate (P) and $30 \mathrm{~kg} / \mathrm{ha}$ potassium $(\mathrm{K})$ to optimise biomass production on sandy to sandy loam soils (Anonymous, 2013). According to Conradie (1994), $25 \mathrm{~kg} / \mathrm{ha} \mathrm{P}$ is required to ensure a good cover crop stand, whilst the $\mathrm{K}$ level in the soil should be at least $40 \mathrm{mg} / \mathrm{kg}$. However, amounts of fertilisers applied to cover crops in vineyards should not exceed the fertiliser needs of the grapevines. The P level in this sandy to sandy loam soil should be $25 \mathrm{mg} / \mathrm{kg}$. Maintenance fertilisation with $\mathrm{K}$ is required at a rate of $3 \mathrm{~kg}$ per ton of grapes produced on soils with a $\mathrm{K}$ content of less than $30 \mathrm{mg} / \mathrm{kg}$ and an exchangeable $\mathrm{K}\left(\mathrm{K}_{\mathrm{ex}}\right)$ /cation exchange capacity (CEC) saturation level of less than $4 \%$. Therefore, the soil nutrient status was monitored throughout the trial period to ensure that the amounts of fertilisers applied did not cause a nutrient imbalance in the grapevines.

The $30 \mathrm{~kg} /$ ha P broadcast during April 2011 (Table 3) increased the P levels in the 0 to $150 \mathrm{~mm}$ soil layer from 31 $\mathrm{mg} / \mathrm{kg}$ (April 2009) to $60 \mathrm{mg} / \mathrm{kg}$ (April 2012) (Table 4). The P concentration in the 150 to $300 \mathrm{~mm}$ soil layer increased from $14 \mathrm{mg} / \mathrm{kg}$ (April 2009) to $23 \mathrm{mg} / \mathrm{kg}$ (April 2012), which is near the norm for vineyard soils (Conradie, 1994). Although an annual application of $25 \mathrm{~kg} / \mathrm{ha}$ of P would help to ensure a good cover crop stand (Conradie, 1994; Anonymous, 2013), the amount of P applied was reduced to $15 \mathrm{~kg} / \mathrm{ha}$ in May 2012 (Table 3), due to the high $\mathrm{P}$ concentration in the 0 to $150 \mathrm{~mm}$ soil layer (Table 4). Subsequently, the amount of P in the 150 to $300 \mathrm{~mm}$ soil layer was maintained at $24 \mathrm{mg} / \mathrm{kg}$, but a further increase of $20 \mathrm{mg} / \mathrm{kg}$ observed in the 0 to 150 $\mathrm{mm}$ soil layer (Table 4) resulted in no $\mathrm{P}$ application during 2013 (Table 3).

From November 2010 onwards, $30 \mathrm{~kg} / \mathrm{ha}$ of $\mathrm{K}$ was broadcast post-harvest (May/June) and during full bloom (late November/early December). The post-harvest application was done to supply the fertiliser needs of the cover crops (Anonymous, 2013). The full bloom application was done to supply the fertiliser needs of the grapevines, which produced $8 \mathrm{t} /$ ha on average, as the $\mathrm{K}$ (Bray II) and $\mathrm{K}_{\mathrm{ex}} / \mathrm{CEC}$ saturation level in the soil were below $30 \mathrm{mg} / \mathrm{kg}$ and $4 \%$ (Table 4 ), the

TABLE 3

Fertilisers broadcast in a Shiraz/101-14 vineyard established on a sandy to sandy clay loam soil near Stellenbosch.

\begin{tabular}{|c|c|c|c|c|c|}
\hline \multirow[b]{2}{*}{ Growing season } & \multirow[b]{2}{*}{ Date } & \multirow[b]{2}{*}{ Stage } & \multicolumn{3}{|c|}{ Amount (kg/ha) } \\
\hline & & & $\mathrm{N}$ & $\mathrm{P}$ & $\mathrm{K}$ \\
\hline $2009 / 2010$ & $15 / 06 / 2009$ & Two- to six-leaf stages of oats cover crop & 28 & 0 & 0 \\
\hline \multirow[t]{2}{*}{$2010 / 2011$} & $12 / 06 / 2010$ & Two- to six-leaf stages of oats cover crop & 28 & 0 & 0 \\
\hline & $11 / 11 / 2010$ & Grapevine flowering stage & 28 & 0 & 30 \\
\hline \multirow[t]{3}{*}{$2011 / 2012$} & $28 / 04 / 2011$ & One week before sowing of cover crops & 28 & 30 & 0 \\
\hline & 09/06/2011 & Two- to six-leaf stages of oats & 28 & 0 & 30 \\
\hline & $30 / 11 / 2011$ & Grapevine full bloom & 28 & 0 & 0 \\
\hline \multirow[t]{3}{*}{$2012 / 2013$} & $09 / 05 / 2012$ & Just after sowing cover crops & 28 & 15 & 30 \\
\hline & $21 / 06 / 2012$ & Two- to six-leaf stages of oats cover crop & 28 & 0 & 0 \\
\hline & $06 / 12 / 2012$ & Grapevine full bloom & 0 & 0 & 30 \\
\hline \multirow[t]{2}{*}{$2013 / 2014$} & $23 / 05 / 2013$ & Just after sowing of cover crops & 28 & 0 & 30 \\
\hline & $20 / 06 / 2013$ & Two- to six-leaf stages of oats cover crop & 28 & 0 & 0 \\
\hline
\end{tabular}


TABLE 4

The average phosphate $(\mathrm{P})$, potassium $(\mathrm{K})$ and exchangeable $\mathrm{K}\left(\mathrm{K}_{\mathrm{ex}}\right)$, as a percentage of the cation exchange capacity $(\mathrm{CEC})$, and total inorganic nitrogen (inorganic $\mathrm{N}_{\text {tot }}$ ) concentrations in the 0 to $75 \mathrm{~mm}, 75$ to $150 \mathrm{~mm}, 150$ to $300 \mathrm{~mm}$ and 300 to 600 $\mathrm{mm}$ soil layers, measured during the grapevine post-harvest period (April).

\begin{tabular}{|c|c|c|c|c|c|c|c|c|c|c|c|c|c|c|c|}
\hline \multirow{2}{*}{$\begin{array}{l}\text { Soil layer } \\
(\mathrm{mm})\end{array}$} & \multicolumn{4}{|c|}{$\begin{array}{l}\text { P (Bray II) } \\
(\mathrm{mg} / \mathrm{kg})\end{array}$} & \multicolumn{4}{|c|}{$\begin{array}{l}\text { K (Bray II) } \\
(\mathrm{mg} / \mathrm{kg})\end{array}$} & \multicolumn{4}{|c|}{$\begin{array}{l}\mathrm{K}_{\mathrm{ex}} / \mathrm{CEC} \\
(\%)\end{array}$} & \multicolumn{3}{|c|}{$\begin{array}{l}\text { Inorganic } N_{\text {tot }} \\
(\mathrm{mg} / \mathrm{kg})\end{array}$} \\
\hline & 2009 & 2011 & 2012 & 2013 & 2009 & 2011 & 2012 & 2013 & 2009 & 2011 & 2012 & 2013 & 2010 & 2012 & 2013 \\
\hline $0-75$ & 38 & 77 & 78 & 104 & 42 & 66 & 60 & 75 & 2.04 & 2.51 & 2.79 & 3.32 & 26 & 40 & 26 \\
\hline $75-150$ & 24 & 39 & 42 & 56 & 26 & 39 & 40 & 38 & 1.91 & 1.45 & 3.03 & 2.08 & 21 & 29 & 22 \\
\hline $150-300$ & 14 & 22 & 23 & 24 & 23 & 33 & 31 & 28 & 1.88 & 2.28 & 2.99 & 2.17 & 17 & 22 & 19 \\
\hline $300-600$ & 9 & 11 & 13 & 10 & 14 & 29 & 25 & 22 & 1.33 & 2.08 & 2.51 & 2.07 & 15 & 19 & 19 \\
\hline
\end{tabular}

levels at which maintenance fertilisation with $\mathrm{K}$ should be applied (Conradie, 1994).

Twenty-eight $\mathrm{kg} / \mathrm{ha} \mathrm{N}$ was broadcast on all the plots at the two- to six-leaf stages of oats, as previously suggested (Fourie \& Raath, 2008; Fourie et al., 2011). From the 2010/2011 season onwards, $28 \mathrm{~kg} / \mathrm{ha} \mathrm{N}$ was applied during November (remaining within the guidelines of Conradie, 1994) to improve the performance of the grapevines. From the 2011/2012 season onwards, all the N was applied postharvest.

\section{Grapevine cultivation practices}

The practices conducted at this site were in accordance with the standard practices applied in South African vineyards. The vineyard was drip irrigated from December through to March. The standard pest and disease management programme used by the farm was applied.

\section{Measurements \\ Soil chemical analyses}

Soil samples were taken from the 0 to $75 \mathrm{~mm}, 75$ to 150 $\mathrm{mm}, 150$ to $300 \mathrm{~mm}$ and 300 to $600 \mathrm{~mm}$ soil layers in all the plots. The soil was sampled from three positions for each layer diagonally across the work row. The composite samples were analysed for $\mathrm{pH}(1.0 \mathrm{M} \mathrm{KCl})$, electrical conductivity (EC), $\mathrm{P}$ and $\mathrm{K}$ (Bray II), exchangeable $\mathrm{K}$, calcium $(\mathrm{Ca})$, magnesium $(\mathrm{Mg})$ and sodium $(\mathrm{Na})$, and for organic carbon. The $\mathrm{EC}_{\mathrm{e}}$ was determined by saturating the soil samples with deionised water, filling a US Bureau of Soil Standards electrode cup with the saturated paste and measuring the $\mathrm{EC}_{\mathrm{e}}$ with a conductivity meter. The samples for the determination of $\mathrm{P}$ and $\mathrm{K}$ were prepared according to the Bray II method (The Non-affiliated Soil Analysis Work Committee, 1990), whereas the exchangeable cations were extracted with an ammonium acetate solution. These samples were analysed using an ICP-OES spectrometer (PerkinElmer Optima 7300 DV, Waltham, Massachusetts, U.S.A.). The organic C content was determined according to the Walkley-Black method (Walkley \& Black, 1934). The ammonium $\mathrm{N}\left(\mathrm{NH}_{4}-\mathrm{N}\right)$ and nitrate $\mathrm{N}\left(\mathrm{NO}_{3}-\mathrm{N}\right)$ were extracted with $1 \mathrm{M} \mathrm{KCl}$ and determined by means of the colorimetric method described by The Non-affiliated Soil Analysis Work Committee (1990).

\section{Soil physical analyses}

Soil samples were taken from the 0 to $300 \mathrm{~mm}$ and 300 to $600 \mathrm{~mm}$ soil layers. Each depth interval was sampled at 10 randomly selected plots covering the three blocks in which the treatments were replicated. The clay, silt and sand fractions were determined on the two composite samples for each soil layer (each consisting of the soil from five of the randomly selected plots) according to the hydrometer method (Van der Watt, 1966). The average values are presented in Table 1 . The soil texture classification was done by means of a texture chart (Soil Classification Working Group, 1991).

\section{Cover crop and weed DMP}

The DMP of both the cover crops and the associated weeds was determined just before grapevine bud break (end of August) and when the grapevine berries reached pea size (end of November), according to the procedure described by Fourie et al. (2001).

\section{Statistical procedures}

The experiment was a complete randomised block design with fourteen treatments replicated three times and repeated for five consecutive seasons (years). The DMP was measured randomly within each experiment plot at the end of both August and November. The data were tested for normality (Shapiro \& Wilk, 1965), found to be acceptably normally distributed, and subjected to analysis of variance. Analyses of variance were performed separately for each season, using the Statistical Analysis System (SAS, 1990). Student's $t$ least significant difference (LSD) was calculated at the 5\% and $10 \%$ significance level to facilitate comparison between the treatment means.

\section{RESULTS AND DISCUSSION \\ Cover crop performance}

During 2009, Avena sativa cv. Pallinup (Pallinup oats), Sinapis alba (white mustard) and Caliente produced similar amounts of dry matter, whereas Nemat performed poorer than these species (Table 5). The DMP of all the cover crop species, with the exception of Pallinup oats in the CC treatment, was higher during 2010 than in 2009. This was attributed to the improved seedbed, as well as the higher rainfall that occurred during the first two weeks of May (Table 6). The fact that August 2010 was slightly warmer than August 2009 (Table 7) could also have contributed 
to the observed increase in DMP. The 0.55 to $2.62 \mathrm{t} / \mathrm{ha}$ increase in dry matter observed for the small-seeded white mustard, canola, Caliente and Nemat (Table 5) confirmed the importance of proper seedbed preparation when these species are considered for cover crop management.

The DMP of all the species, with the exception of white mustard (CC), was higher in the 2011/2012 season compared to that of the previous season (Table 5). This was attributed to the additional $\mathrm{P}$ and $\mathrm{N}$ applied one week before sowing, as well as the K applied at the two- to six-leaf stages (Table 3), contributing to a more acceptable level of $\mathrm{K}$, especially in the 0 to $75 \mathrm{~mm}$ and 75 to $150 \mathrm{~mm}$ soil layers (Table 4). Although May 2011 was $0.6^{\circ} \mathrm{C}$ warmer than May 2010, the average temperatures of the two cover crop growing seasons were similar (Table 7), indicating that temperature made a minor contribution to the observed increases in DMP during this season (Table 5). Although it did not rain during the second and third week after the cover crops were sown, the $71 \mathrm{~mm}$ rain that fell between 2011-04-24 and 2011-05-07 (Table 6) seemed sufficient to ensure the successful germination of the cover crop seeds and sustain growth during the first three weeks.

The DMP of the four broadleaf cover crops that were selected for their bio-fumigation properties was lower than that of Pallinup oats during the 2012/2013 season and produced less fibre than during the previous two seasons (Table 5). This decline in performance occurred despite an application of $\mathrm{N}, \mathrm{P}$ and $\mathrm{K}$ just after the crops were sown
(Table 3). The observed trend was attributed to the May 2012 temperatures being $0.6^{\circ} \mathrm{C}$ and $1.2^{\circ} \mathrm{C}$ lower than they were in May 2010 and in May 2011 respectively, as well as the average temperature from May 2012 to August 2012 being approximately $1.4^{\circ} \mathrm{C}$ lower than that of the previous two seasons (Table 7). This indicated that the four broadleaf species were more sensitive to lower temperatures than Pallinup oats. Although the cover crops could only be sown late (23 May 2013), the DMP of the oats still improved slightly compared to 2012 (Table 5). It seems that the relatively high rainfall during the first five weeks following the sowing of the cover crops (Table 6), the temperatures during May, July and August being higher than those of the previous season (Table 7), as well as the $\mathrm{K}$ being higher in the 0 to $75 \mathrm{~mm}$ and 75 to $150 \mathrm{~mm}$ soil layers (Table 4) contributed to the observed increase in DMP (Table 5). The aforementioned edaphic conditions also resulted in the DMP of canola during 2013 being higher than in the 2012 season. However, white mustard, Caliente and Nemat performed slightly poorer in 2013 than in the previous season, indicating that these species need to be sown earlier. Although the DMP of the broadleaf cover crops was lower than that of Pallinup oats for the second consecutive season (Table 5), it was, with the exception of Nemat (MC), similar to the DMP levels reported by Fourie et al. (2001) for oats and Secale cereale (rye) established in early May on a medium-textured soil near Stellenbosch that was irrigated over the full surface by means of micro-sprinklers.

TABLE 5

Effect of soil management on cover crop performance and control of winter-growing weeds measured at the end of August.

\begin{tabular}{|c|c|c|c|c|c|c|c|c|c|c|}
\hline \multirow[b]{3}{*}{ Treatment } & \multicolumn{10}{|c|}{ Dry matter production (t/ha) } \\
\hline & \multicolumn{2}{|c|}{2009} & \multicolumn{2}{|c|}{2010} & \multicolumn{2}{|c|}{2011} & \multicolumn{2}{|c|}{2012} & \multicolumn{2}{|c|}{2013} \\
\hline & $\begin{array}{l}\text { Cover } \\
\text { crop }\end{array}$ & Weeds & $\begin{array}{l}\text { Cover } \\
\text { crop }\end{array}$ & Weeds & $\begin{array}{l}\text { Cover } \\
\text { crop }\end{array}$ & Weeds & $\begin{array}{l}\text { Cover } \\
\text { crop }\end{array}$ & Weeds & $\begin{array}{l}\text { Cover } \\
\text { crop }\end{array}$ & Weeds \\
\hline $\begin{array}{l}\text { 1. Avena sativa L. cv. Pallinup } \\
\text { (Pallinup oats), } \mathrm{CC}^{1}\end{array}$ & 3.29 & 0.33 & 2.48 & 0.18 & 5.66 & 0 & 5.60 & 0.13 & 5.73 & 0.09 \\
\hline 2. Pallinup oats, $\mathrm{MC}^{2}$ & 2.10 & 0.41 & 2.49 & 0.25 & 2.52 & 0.81 & 5.08 & 0.30 & 5.98 & 0.12 \\
\hline $\begin{array}{l}\text { 3. Sinapis alba cv. Braco } \\
\text { (white mustard), CC }\end{array}$ & 2.70 & 0.38 & 4.96 & 0 & 4.48 & 1.06 & 3.49 & 0.20 & 3.57 & 0.02 \\
\hline 4. White mustard, MC & 2.57 & 0.37 & 3.21 & 1.20 & 5.12 & 0.72 & 3.01 & 0.46 & 2.66 & 0.60 \\
\hline $\begin{array}{l}\text { 5. Brassica napus cv. AVJade } \\
\text { (canola), CC }\end{array}$ & 1.81 & 0.69 & 2.36 & 0.66 & 4.39 & 0.66 & 0.87 & 0.34 & 3.06 & 0.30 \\
\hline 6. Canola, MC & 1.64 & 1.09 & 2.22 & 1.07 & 3.98 & 1.05 & 1.71 & 1.93 & 3.79 & 0.20 \\
\hline $\begin{array}{l}\text { 7. Brassica juncea cv. Caliente } \\
199 \text { (Caliente), CC }\end{array}$ & 2.37 & 0.36 & 3.08 & 0.16 & 5.23 & 0.04 & 2.91 & 0.11 & 2.36 & 0.20 \\
\hline 8. Caliente, $\mathrm{MC}$ & 2.43 & 0.47 & 3.08 & 0.35 & 5.62 & 0.27 & 2.75 & 0.32 & 2.02 & 0.29 \\
\hline $\begin{array}{l}\text { 9. Eruca sativa cv. Nemat } \\
\text { (Nemat), CC }\end{array}$ & 0.71 & 0.92 & 3.33 & 0.01 & 5.13 & 0.36 & 2.24 & 0.32 & 2.07 & 0.17 \\
\hline 10. Nemat, MC & 0.95 & 0.63 & 1.62 & 0.90 & 1.79 & 2.45 & 1.57 & 1.16 & 1.41 & 0.57 \\
\hline 11. Weeds, CC & 0 & 3.74 & 0 & 3.15 & 0 & 3.69 & 0 & 3.51 & 0 & 4.49 \\
\hline 12. Weeds, MC & 0 & 3.30 & 0 & 3.45 & 0 & 4.58 & 0 & 3.39 & 0 & 3.51 \\
\hline 13. Weeds, nematicide, CC & 0 & 3.08 & 0 & 3.79 & 0 & 2.87 & 0 & 3.40 & 0 & 4.10 \\
\hline 14. Weeds, nematicide, $\mathrm{MC}$ & 0 & 2.38 & 0 & 3.28 & 0 & 4.57 & 0 & 2.80 & 0 & 4.59 \\
\hline $\operatorname{LSD}(\mathrm{p} \leq 0.05)$ & 1.18 & 1.23 & 1.03 & 0.86 & 1.39 & 1.55 & 1.08 & 1.07 & 1.41 & 1.35 \\
\hline
\end{tabular}

${ }^{1}$ Full-surface chemical control from grapevine bud break. ${ }^{2}$ Chemical control in vine row, mechanical incorporation in work row from grapevine bud break, full-surface chemical control from berry set. 
TABLE 6

Winter rainfall for the period 17 April to 27 August measured over five seasons at Alto weather station, close to the trial site.

\begin{tabular}{llllll}
\hline & \multicolumn{5}{c}{ Winter rainfall $(\mathrm{mm})$} \\
\cline { 2 - 5 } Period & 2009 & 2010 & 2011 & 2012 & 2013 \\
\hline 17 April to 23 April & 21 & 13 & 2 & 0 & 25 \\
24 April to 30 April & 23 & 0 & 42 & 24 & 1 \\
1 May to 7 May & 14 & 37 & 29 & 36 & 8 \\
8 May to 14 May & 6 & 75 & 0 & 1 & 6 \\
15 May to 21 May & 59 & 0 & 0 & 22 & 1 \\
22 May to 28 May & 7 & 28 & 50 & 23 & 40 \\
29 May to 4 June & 34 & 1 & 35 & 10 & 83 \\
5 June to 11 June & 28 & 33 & 10 & 70 & 23 \\
12 June to 18 June & 34 & 59 & 44 & 5 & 21 \\
19 June to 25 June & 46 & 6 & 50 & 23 & 35 \\
26 June to 2 July & 4 & 12 & 29 & 17 & 1 \\
3 July to 9 July & 2 & 7 & 2 & 50 & 2 \\
10 July to 16 July & 65 & 56 & 0 & 25 & 7 \\
17 July to 23 July & 10 & 5 & 0 & 44 & 74 \\
24 July to 30 July & 5 & 1 & 15 & 17 & 34 \\
31 July to 6 August & 33 & 0 & 30 & 47 & 20 \\
7 August to 13 August & 24 & 25 & 18 & 41 & 67 \\
14 August to 20 August & 33 & 6 & 10 & 47 & 52 \\
21 August to 27 August & 6 & 35 & 24 & 24 & 18 \\
Total winter rainfall & 454 & 399 & 390 & 526 & 518 \\
\hline
\end{tabular}

TABLE 7

Average monthly winter air temperatures from May to August measured over five seasons at Alto weather station, close to the trial site.

\begin{tabular}{llllll}
\hline & \multicolumn{5}{c}{ Temperature $\left({ }^{\circ} \mathrm{C}\right)$} \\
\cline { 2 - 6 } Month & 2009 & 2010 & 2011 & 2012 & 2013 \\
\hline May & 16.2 & 16.0 & 16.7 & 15.5 & 17.5 \\
June & 14.8 & 14.8 & 14.2 & 14.1 & 13.8 \\
July & 15.2 & 14.5 & 15.3 & 13.2 & 14.2 \\
August & 14.3 & 14.8 & 14.5 & 12.3 & 13.1 \\
\hline
\end{tabular}

\section{Suppression of winter-growing weeds}

Despite differences in DMP, all the cover crop species, except for the canola in the MC treatment during 2012, suppressed the winter-growing weeds throughout the study (Table 5). The winter-growing weeds were effectively suppressed (less than $10 \%$ of the weed stand measured in the treatments in which no cover crop was sown) by the CC treatments of Pallinup oats, Caliente and white mustard throughout the study, with the exception of white mustard (CC) during 2011. Total winter weed suppression was achieved with white mustard (CC) and Pallinup oats (CC) during 2010 and 2011 respectively. Nemat (CC) and Caliente (MC) suppressed the winter-growing weeds effectively during 2010 and 2011 respectively. All the cover crop treatments suppressed the winter-growing weeds effectively during 2013 (fifth season which the treatments were applied), indicating that all the species selected for their bio-fumigation properties could provide in effective winter weed suppression over the medium term.

\section{Suppression of summer-growing weeds}

The two management practices applied, as well as the different cover crop species, had no significant effect on the weed stand measured at the end of November 2009 (Table 8). Although the stand of summer-growing weeds differed significantly between treatments during the following three seasons (2010, 2011 and 2012), none of the cover crop treatments reduced the weed stand significantly compared to the treatments in which no cover crop was sown. However, the weed stand in the CC treatments of oats and mustard was lower than in the corresponding MC treatments in November 2010. Although not significant, this trend was also observed for canola, Caliente and Nemat. During the 2011 and 2012 seasons, a similar trend was observed for all 
Table 8

Effect of different soil management practices on the stand of summer-growing weeds measured at the end of November.

\begin{tabular}{lcccc}
\hline & \multicolumn{3}{c}{ Dry matter production (t/ha) } \\
\cline { 2 - 5 } Treatment & 2009 & 2010 & 2011 & 2012 \\
\hline 1. Avena sativa L. cv. Pallinup (Pallinup oats), CC & 1.00 & 0.21 & 0.06 & 0.07 \\
2. Pallinup oats, MC ${ }^{1}$ & 0.85 & 0.79 & 0.29 & 0.81 \\
3. Sinapis alba cv. Braco (white mustard), CC & 0.98 & 0.10 & 0.24 & 0.20 \\
4. White mustard, MC & 0.85 & 0.60 & 0.03 & 0.47 \\
5. Brassica napus cv. AVJade (canola), CC & 0.65 & 0.18 & 0.02 & 0.17 \\
6. Canola, MC & 0.78 & 0.50 & 0.19 & 0.53 \\
7. Brassica juncea cv. Caliente 199 (Caliente), CC & 0.73 & 0.54 & 0.33 & 0.15 \\
8. Caliente, MC & 0.45 & 0.66 & 0.15 & 0.60 \\
9. Eruca sativa cv. Nemat (Nemat), CC & 0.69 & 0.17 & 0.01 & 0.59 \\
10. Nemat, MC & 0.57 & 0.38 & 0.07 & 0.51 \\
11. Weeds, CC & 0.61 & 0.56 & 0.04 & 0.10 \\
12. Weeds, MC & 1.24 & 0.49 & 0.78 & 0.64 \\
13. Weeds, nematicide, CC & 0.72 & 0.53 & 0.14 & 0.43 \\
14. Weeds, nematicide, MC & 1.13 & 0.45 & 0.52 & 0.70 \\
LSD (p $\leq$ 0.05) & $\mathrm{NS} 3$ & 0.41 & 0.37 & 0.33 \\
\hline
\end{tabular}

${ }^{1}$ Full-surface chemical control from grapevine bud break. ${ }^{2} \mathrm{Chemical}$ control in vine row, mechanical incorporation in work row from grapevine bud break, full-surface chemical control from berry set. ${ }^{3}$ Does not differ significantly, $10 \%$ level.

treatments, except for white mustard and Caliente during 2011, and Nemat during 2012. During the last-mentioned season, the trend was significant for Pallinup oats, canola, Caliente and the two treatments in which no nematicide was applied and in which no cover crop was sown. The observed trend was attributed to the presence of a surface mulch in the CC treatments, as well as to the mechanical cultivation applied in the MC treatments during September, which may have promoted the germination of weeds during early summer.

\section{CONCLUSIONS}

The quality of the seedbed, as well as relatively low winter temperatures, had a greater effect on the performance of the small-seeded white mustard, canola, Caliente and Nemat than on the larger seeded Pallinup oats. On sandy to sandy clay loam soils, the cover crops should receive $\mathrm{N}, \mathrm{K}$ and $\mathrm{P}$ from just before planting up until the six-leaf stage to maximise their performance. However, the application of $\mathrm{P}$ should be done judiciously, as it may accumulate and reach high concentrations in the 0 to $75 \mathrm{~mm}$ and 75 to $150 \mathrm{~mm}$ soil layers within a very short period of time.

All the cover crop species suppressed the winter-growing weeds effectively after five seasons, with immediate and sustainable effective control being achieved with Pallinup oats and Caliente. Chemical control of the cover crops or weeds seems to improve the control of summer-growing weeds.

Caliente, canola, white mustard and Nemat, which were selected primarily for their biofumigation properties, can be included in a cover crop rotation system for grapevines without compromising weed-control efficacy.

\section{LITERATURE CITED}

Addison, P. \& Fourie, J.C., 2008. Cover crop management in the vineyards of the Lower Orange River region, South Africa: 2. Effect on plant parasitic nematodes. S. Afr. J. Enol. Vitic. 29, 26-32.

Anonymous, 2013. Canola production manual. Retrieved from http://www. overbergagri.co.za/documents/agri/canola\%20manual.pdf on 4 July 2014.

Booysen, J.H., Steenkamp, J. \& Archer, E., 1992. Names of vertical trellising systems (with abbreviations). Wynboer September, 15.

Buckerfield, J.C. \& Webster, K.A., 1996. Earthworms, mulching, soil moisture and grape yields. Wine Indust. J. 11, 47-53.

Conradie, W.J., 1994. Vineyard fertilization. Proceedings of a workshop on vineyard fertilization, Nietvoorbij, 30 September, ARC - Fruit, Vine and Wine Research Institute, Private Bag X5026, 7599 Stellenbosch, South Africa.

Cousens, R. \& Mortimer, M., 1995 ( $1^{\text {st }}$ ed). Dynamics of weed populations. Cambridge University Press, Cambridge.

Fourie, J.C., 2005. Cover crop management in the vineyards of the Lower Orange River region, South Africa: 1. Performance of grass and broadleaf species. S. Afr. J. Enol. Vitic. 26, 140-146.

Fourie, J.C., 2010. Soil management in the Breede River Valley wine grape region, South Africa. 1. Cover crop performance and weed control. S. Afr. J. Enol. Vitic. 31, 14-21.

Fourie, J.C. \& Freitag, K., 2010. Soil management in the Breede River Valley Wine Grape Region, South Africa. 2. Soil temperature. S. Afr. J. Enol. Vitic. 31, 165-168.

Fourie, J.C., Joubert, M. \& Freitag, 2011. Effect of organic and integrated soil management practices on the weed population in a Pink Lady apple orchard in the Elgin region. SA Fruit Journal February/March, 41-47. 
Fourie, J.C., Louw, P.J.E. \& Agenbag, G.A., 2001. Effect of seeding date on the performance of grasses and broadleaf species evaluated for cover crop management in two wine grape regions of South Africa. S. Afr. J. Plant Soil $18,118-127$.

Fourie, J.C., Louw, P.J.E. \& Agenbag, G.A., 2005. Cover crop management in a Sauvignon blanc/Ramsey vineyard in the semi-arid Olifants River Valley, South Africa. 1. Effect of management practices on selected grass and broadleaf species. S. Afr. J. Enol. Vitic. 26, 131-139.

Fourie, J.C., Louw, P.J.E. \& Agenbag, G.A., 2006. Cover crop management in a Chardonnay/99 Richter vineyard in the coastal wine grape region, South Africa. 1. Effect of two management practices on selected grasses and broadleaf species. S. Afr. J. Enol. Vitic. 27, 167-177.

Fourie, J.C. \& Raath, P.J., 2008. Effect of organic and integrated soil cultivation practices on the weed population in a Sauvignon blanc vineyard situated in the Drakenstein area of the Paarl wine district. Wineland 59-63.

Khan, M.J., Monke, E.J. \& Foster, G.R., 1986. Mulch cover and canopy effect on soil loss. Pap. ASAE no 86-253. Dept of Agric. Eng. Purdue Univ. West Lafayette, In. 47907, USA.

Kruger, D.H.M., Fourie, J.C. \& Malan, A.P., 2013. Cover crops with biofumigation properties for the suppression of plant-parasitic nematodes: A review. S. Afr. J. Enol. Vitic. 34, 287-295.

LeBaron, H.M., 1991. Distribution and seriousness of herbicide-resistant weed infestations worldwide. In: Caseley, J.C., Cussans, G.W. \& Atkin, R.K. (eds). Herbicide resistance in weeds and crops. Butterworth-Heinemann, Boston. pp. $27-43$.

LeBaron, H.M. \& McFarland, J.E., 1990. Herbicide resistance in weeds and crops: An overview and prognosis. In: Green, M.B., LeBaron, H.M \& Moberg, W.K. (eds). Managing resistance to agrochemicals: From fundamental research to practical strategies. Am. Chem. Soc., Washington DC. pp $336-352$.

Louw, P.J.E. \& Bennie, A.T.P., 1992. Water runoff and soil erosion in vineyard soils. Aust. Grapegrower \& Winemaker Annual Technical Issue, 100-113.

Matthiessen, J.N. \& Kirkegaard, J.A., 2006. Biofumigation and enhanced biodegradation: Opportunity and challenge in soilborne pest and disease management. Critical Rev. Plant Sci. 25, 235-265.

Matthiessen, J.N., Warton, B. \& Schackleton, M.A., 2004. The importance of plant maceration and water addition in achieving high Brassica-derived isothiocyanate levels in the soil. Agroindustria 3, 277-280.

McLeod, R.W. \& Steel, C.C., 1999. Effects of brassica-leaf green manures and crops on the activity and reproduction of Meloidogyne javanica. Nematol. 1, 613-624.

Melakeberhan, H., Xu, A., Kravchenko, A., Mennan, S. \& Rika, E., 2006. Potential use of aragula (Eruca sativa L.) as a trap crop for Meloidogyne hapla. Nematol. 8, 793-799.
Mojtahedi, H., Santo, G.S., Hang, A.N. \& Wilson, J.H., 1991. Suppression of root-knot nematode populations with selected rapeseed cultivars as green manure. J. Nematol. 23, 170-174.

Myburgh, P.A., 1998. Water consumption of South African vineyards: A modeling approach based on the quantified combined effects of selected viticultural, soil and meteorological parameters. $\mathrm{PhD}$ dissertation, Stellenbosch University, Private Bag X1, 7602 Matieland (Stellenbosch), South Africa.

Myburgh, P.A., 2013. Effect of shallow tillage and straw mulching on soil water conservation and grapevine response. S. Afr. J. Plant Soil 30, 219225 .

Powles, S.B., Preston, C., Bryan, I.B. \& Jutsum, A.R., 1997. Herbicide resistance impact and management. Adv. Agron. 58, 57-93.

Rahman, L. \& Somers, T., 2005. Suppression of root knot nematode (Meloidogyne javanica) after incorporation of Indian mustard cv. Nemfix as green manure and seed meal in vineyards. Austr. Plant Pathol., 34, 77-83.

Roth, C.H., Meyer, B., Frede, G. \& Derpsch, R., 1988. Effect of mulch rates and tillage systems on infiltrabillity and other soil physical properties of an Oxisol in Parana, Brazil. Soil \& Tillage Res. 11, 81-91.

Statistical Analysis System (SAS), 1990. SAS/STAT users guide, version 8, vol. 2. SAS Institute Inc., Campus Drive, Cary NC.

Shapiro, S.S. \& Wilk, M.B., 1965. An analysis of variance test for normality (complete samples). Biometrika 52, 591-611.

Soil Classification Work Group, 1991. Soil classification - A taxonomic system for South Africa. Memoirs on natural agricultural resources of South Africa No. 15, Dept. of Agric. Develop., Private Bag X144, 0001 Pretoria, South Africa.

The Non-Affiliated Soil Analysis Work Committee, 1990. Handbook of standard soil testing methods for advisory purposes. Soil Sci. Soc. South Africa, P.O. Box 30030, 0132 Sunnyside, South Africa.

Van der Watt, H.V.H., 1966. Improved tables and a simplified procedure for the soil particle size analyses by the hydrometer method. S. Afr. J. Agric. Sci. 9, 911-916.

Van Huyssteen, L., Van Zyl, J.L. \& Koen, A.P., 1984. The effect of cover crop management on soil conditions and weed control in a Colombar vineyard in Oudtshoorn. S. Afr. J. Enol. Vitic. 5, 7-17.

Walkley, A. \& Black, I.A., 1934. An examination of the Degtjareff method for determining organic carbon in soils: Effect of variation in digestion conditions and of inorganic soil constituents. Soil Sci. 63, 251-263.

Westra, P., Wilson, R.G., Miller, S.D., Stahlman, P.W., Wicks, G.W., Chapman, P.L., Withrow, J., Legg, D., Alford, C. \& Gaines, T.A., 2008. Weed population dynamics after six years under glyphosate- and conventional herbicide-based weed control strategies. Crop Sci. 48, 1170-1177. 